\title{
Active Learning Training with Mathematics Tools at SD HKBP Pembangunan 3 Medan
}

\author{
Yan Batara Putra Siringoringo ${ }^{1 *}$, Esther Sorta Mauli Nababan ${ }^{1}$, Asima Manurung ${ }^{1}$, James \\ Piter Marbun ${ }^{1}$, Normalina Napitupulu ${ }^{1}$, J.L. Marpaung ${ }^{1}$ \\ ${ }^{1}$ Department of Mathematics, Faculty of Mathematics and Science, Universitas Sumatera \\ Utara, Medan, Indonesia
}

*Email: yan.batara @usu.ac.id

\begin{abstract}
Education is an attempt by the Government to increase the country's potential to be able to compete with other countries that are experiencing very rapid development. The development of education will have an influence on the life of the local community, that is, it can affect various aspects of life, be it social, economic, cultural, religious, language and also the environment. The extent of the influence of educational development on aspects of life can be studied independently. Besides that, education also plays a major role in expanding employment opportunities, encouraging activities of supporting industries, introducing natural and cultural beauty that is inseparable from a sense of increasing brotherhood in the national and international environment. This is because education itself creates multiple economic impacts, namely direct, indirect, and secondary impacts, which provide opportunities for the growth of businesses and the role of local communities in the education sector. This research will discuss about Active Learning Training with Mathematics Tools at SDS HKBP Pembangunan 3 Medan. The result achieved is that schools are able to provide effective services online in the face of changing times caused by Covid-19 and can provide more information regarding the location of tourist objects that will be traversed by local and foreign tourists
\end{abstract}

Keywords: Mathematics, Educational Objects, Distance Learning

\begin{abstract}
Abstrak
Pendidikan merupakan satu usaha Pemerintah dalam meningkatkan potensi negeri untuk dapat bersaing dengan negara lain yang mengalami perkembangan sangat pesat. Perkembangan pendidikan akan memberikan pengaruh terhadap kehidupan masyarakat setempat, yakni dapat mempengaruhi berbagai aspek kehidupan, baik itu sosial, ekonomi, budaya, religi, bahasa dan juga lingkungannya. Luasnya pengaruh perkembangan pendidikan terhadap aspek kehidupan dapat dikaji secara mandiri. Disamping itu, pendidikan juga berperan besar dalam perluasan lapangan kerja, mendorong kegiatan-kegiatan industri penunjang, memperkenalkan keindahan alam dan budaya yang tak terlepas dari rasa untuk meningkatkan persaudaraan dalam lingkungan nasional dan internasional. Hal ini dikarenakan pendidikan sendiri menciptakan dampak ekonomi multiganda yaitu dampak langsung, tak langsung, ikutan, yang memberi peluang bagi tumbuhnya usaha dan peran masyarakat lokal dalam sektor kependidikanan. Penelitian ini akan membahas tentang Pelatihan Pembelajaran Aktif Dengan Alat Matematika Di SDS HKBP Pembangunan 3 Medan. Hasil yang dicapai adalah sekolah mampu menyediakan pelayanan yang efektif secara daring dalam menghadapi perubahan zaman yang diakibatkan karena Covid-19 dan dapat lebih memberikan informasi terkait lokasi objek wisata yang akan dilalui oleh turis lokal dan mancanegara
\end{abstract}

\section{Kata Kunci: Matematika, Objek Pendidikan, Pembelajaran Jarak Jauh}

\section{PENDAHULUAN}

Secara umum siswa Sekolah Dasar memandang pelajaran matematika adalah pelajaran yang sulit dan membosankan. Selain siswa, guru juga mengalami kesulitan dalam menyampaikan materi, diantaranya keterbatasan waktu dalam menyampaikan materi yang cukup banyak, dan kurangnya ketertarikan siswa belajar matematika apabila menggunakan metode pembelajaran konvensional seperti dari buku pelajaran dan penjelasan dari guru saja. Oleh karena itu perlu diusahakan dalam proses pembelajaran matematika harus lebih menarik lebih interaktif dan menyenangkan. 
Dalam hal mencari solusi untuk mengatasi masalah tersebut, sehingga dapat meningkatkan minat belajar dan prestasi belajar siswa pada semua pelajaran. Dalam kegiatan belajar mengajar ketidakjelasan dan banyaknya materi yang disampaikan dapat dibantu dengan menghadirkan media sebagai perantara. Kerumitan bahan pelajaran dapat disederhanakan dengan bantuan media, karena media dapat mewakili apa yang kurang mampu disampaikan melalui kata-kata atau kalimat. Oleh karena itu dalam rangka membantu meningkatkan mutu pendidikan dan pengajaran matematika khususnya, maka perlu memanfaatkan perkembangan teknologi komputer.

Penggantian sistem ini diharapkan dapat memberikan informasi yang akurat, menghemat biaya dan waktu, sehingga dalam proses belajar mengajar seluruh siswa dapatmengerti materi pelajaran tersebut. Begitu juga perancangan animasi ini dapat memberikan motivasi terhadap siswa dalam hal pembelajaran matematika khususya masalah bangun bidang dan ruang.

\section{METODE PELAKSANAAN}

Kegiatan ini akan dilaksanakan pada kurun waktu Bulan Juni sampai dengan Bulan November dengan memberikan pelatihan bagi guru dan siswa/i SDS HKBP Pembangunan 3 Medan dengan tujuan, guru dapat melaksanakan kegiatan belajar mengajar menggunakan metode pembelajaran aktif berbasis alat matematika. Pelaksana pengabdian akan memberikan pelatihan tentang penyiapan Rencana Proses Pembelajaran berbasis Pembelajaran Aktif. Selanjutnya juga diberikan pelatihan Pembuatan Bahan Ajar yang berbasis Metode Pembelajaran Aktif dengan menggunakan Alat Matematika, baik menggunakan Power Point maupun penyiapan bahan berbentuk video pembelajaran.

Pelaksanaan Pengabdian ini akan dilakukan dalam dua tahapan besar, yaitu:

1. Pelatihan Penyiapan Rencana Proses Pembelajaran dan Pembuatan Bahan Ajar berbasis Alat Matematika.

2. Pelatihan kegiatan belajar mengajar secara Daring

Diperkirakan kegiatan ini akan dilaksanakan pada Bulan Juli 2020 sebelum tahun ajaran baru dimulai.

Metode yang akan dilakukan pada pelaksanaan pengabdian ini adalah :

1. Mendapatkan data yang berupa informasi yang diambil dari buku atau kurikulum pelajaran matematika khusus materi yang akan dibuat aplikasi pembelajaran nya.

2. Melakukan identifikasi bagaimana membuat agar materi yang dikaji menjadi lebih mudah dipelajari oleh siswa SD.

3. Untuk menarik minat belajar siswa pada materi ini, akan dibuat aplikasi pembelajaran yang materinya dikemas seefisien mumgkin, sehingga siswa dapat berinteraksi dengan aplikasi tersebut.

4. Melakukan perancangan aplikasi pembelajaran, mulai dari membuat tampilan aplikasi, penyusunan materi, latihan dan soal.

Setelah perancangan rampung dan diperoleh hasil yang maksimal, maka dilakukan pembagian aplikasi ini ke sekolah dan membuat pelatihan /workshop kepada guru matematika atau siswa.

\section{HASIL DAN PEMBAHASAN}

Pada pelaksanaan pengabdian yang telah dilaksanakan pada hari sabtu 15 agustus 2020 di SDS HKBP Pembangunan 3 yaitu kunjungan tim pengabdian sebanyak 2 kali yaitu kunjungan tim pengabdian pada hari sabtu 11 juli 2020 dengan agenda forum group discussion (FGD) yang membahas terkait isu yang sedang berkembang di lingkungan sekolah dan rencana program yang akan dilaksanakan demi menjawab persoalan yang sedang dihadapi oleh sekolah terutama terkait pembelajaran secara daring dalam menghadapi tatanan pembelajaran baru secara jarak jauh (PJJ). Selanjutnya kunjungan kedua pada hari sabtu 15 agustus 2020 dilaksanakan pelatihan pembelajaran secara daring kepada guru dan staff tata usaha SDS HKBP Pembangunan 3. Demi mendukung proses pelatihan pembelajaran secara 
daring tim pengabdian memberikan beberapa sarana dan prasarana berupa laptop, media penyimpanan flashdisk, dan beberapa peralatan pendukung yang dibutuhkan SDS HKBP Pembangunan 3.

\section{Focus Group Discussion (FGD)}

Kegiatan FGD bertujuan untuk melakukan diskusi awal dalam mempelajari dan mengetahui perkembangan sekolah didalam melaksanakan pembelajaran untuk siswa/i di SDS HKBP Pembangunan 3. Kegiatan dihadiri oleh Kepala Sekolah SDS HKBP Pembangunan 3, Guru, pegawai Tata Usaha, dan Orang tua murid. Kegiatan dibuka oleh ketua Tim Pengabdian Pada Masyarakat dan di bawakan oleh anggota Tim pengabdian pada masyarakat.

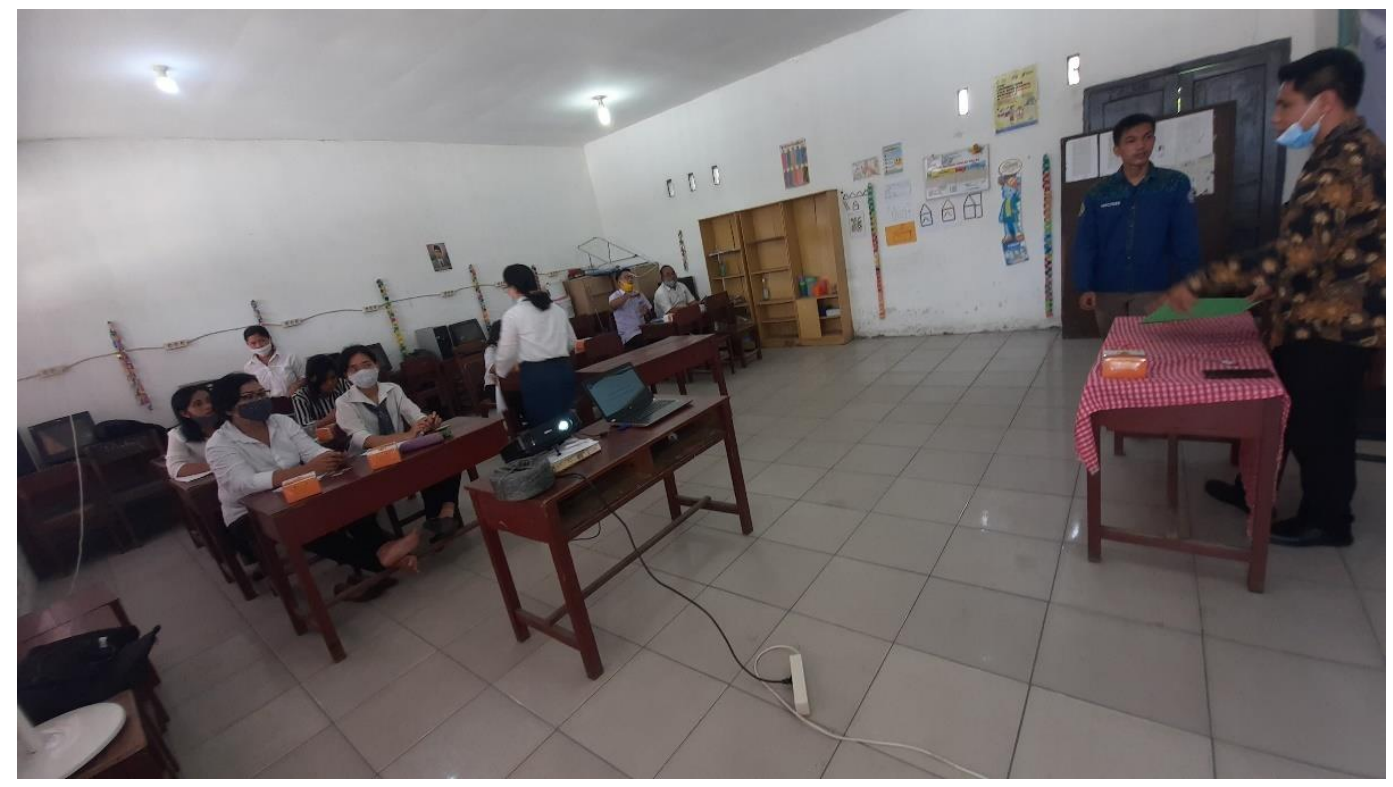

Gambar 1 Kata Sambutan Ketua Pengabdian USU

Melalui FGD Ketua Tim pengabdian USU memaparkan segala kontribusi dan solusi yang akan diberikan oleh perguruan tinggi khususnya USU dalam membekali sekolah di dalam menghadapi tantangan revolusi industri 4.0 terutama dalam hal mengahadapi perubahan pembelajaran akibat pandemic Covid-19, sehingga dengan pembekalan dan pelatihan yang diberikan dapat meningkatkan kualitas sumber daya manusia yang ada di SDS HKBP Pembangunan 3.

Adapun kegiatan ini mengikutsertakan alumni SDS HKBP Pembangunan 3, Staf, Guru dan masyarakat. Dari hasil diskusi disepakati bahwasanya bantuan sarana dan prasarana sangat dibutuhkan oleh SDS HKBP Pembangunan 3. Alumni juga sebagai stackholder menyepakati bahwasanya dari FGD ini akan membantu perkembangan SDS HKBP Pembangunan 3 semaksimal mungkin demi mewujudkan pendidikan di SDS HKBP Pembangunan 3 semakin lebih baik dan menghasilkan alumni-alumni yang bisa dibanggakan suatu saat nanti. 


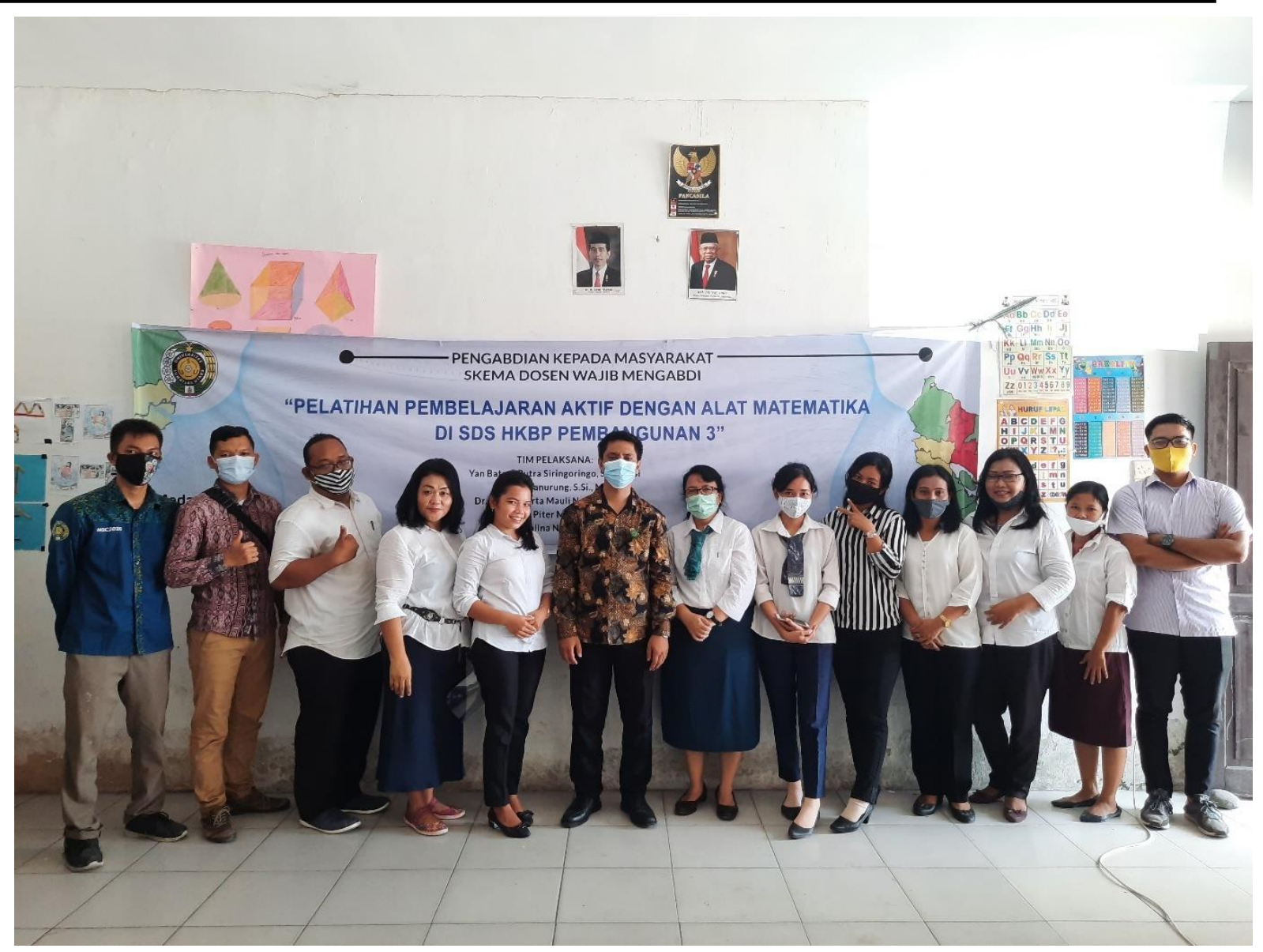

Gambar 2 Foto bersama Alumni, Staf dan Guru SDS HKBP Pembangunan 3

\section{Pelatihan Pembelajaran Aktif di Sekolah}

Pada tahap kedua telah dilakukan pelatihan di dalam pelatihan pembelajaran aktif di sekolah secara daring yang ditujukan kepada guru dan staf SDS HKBP Pembangunan 3. Pelatihan dipimpin langsung oleh ketua Tim dalam memberikan metode pembelajaran yang berbeda yang dapat di terapkan kepada siswa/i di sekolah. Pelatihan yang dilakukan diharapkan mampu memberikan edukasi kepada para guru supaya tidak melupakan nilai-nilai yang harus dilakukan disetiap kegiatan belajar mengajar yang akan dilakukan seperti mengucap salam, berdoa, menyanyikan lagu bernuansa Nasionalisme dan nilai-nilai Pancasila ditengah-tengah kehidupan bermasyarakat. 


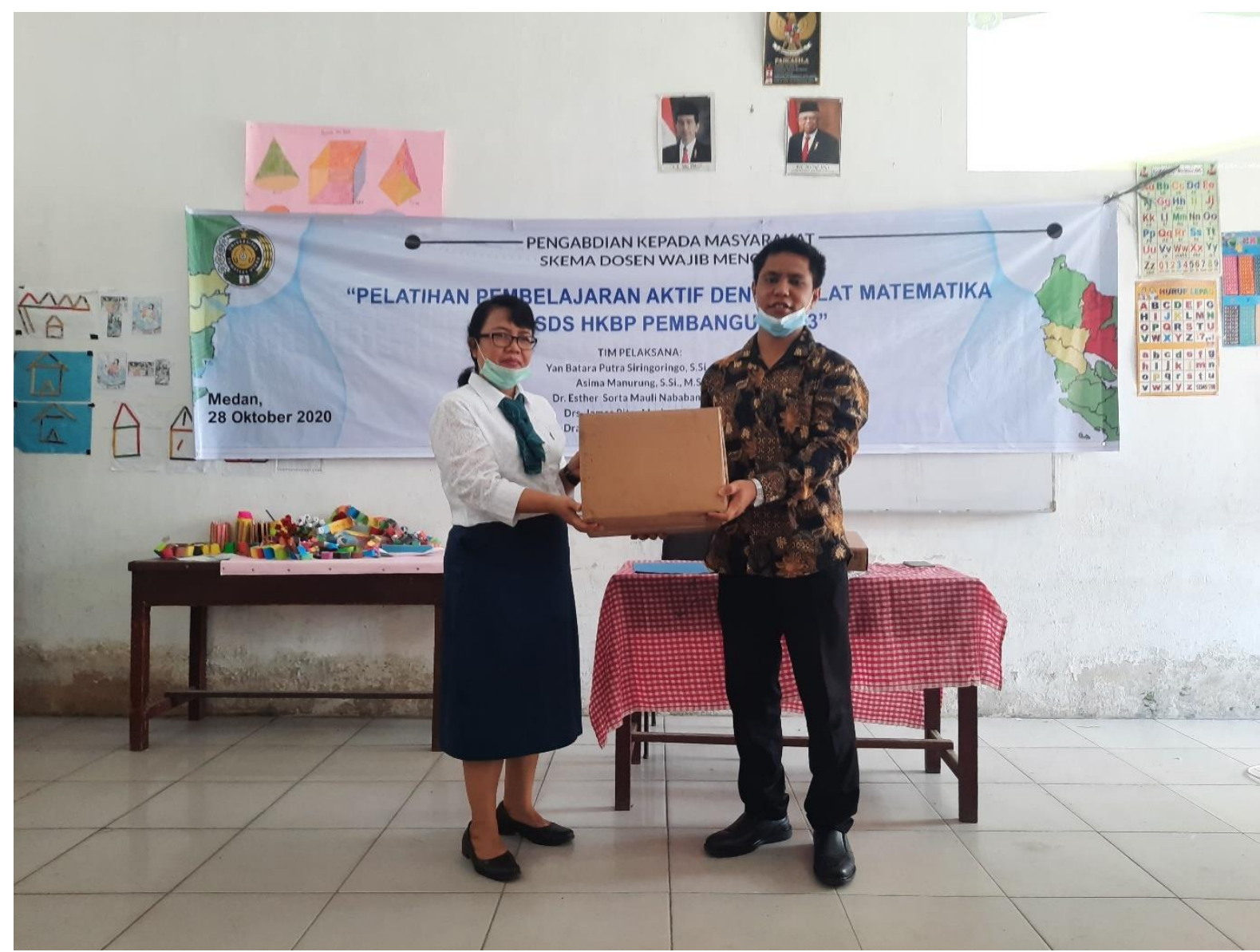

Gambar 3 Serah Terima Perangkat Pendukung Pembelajaran Aktif di Sekolah

selanjutnya dilakukan serah terima perangkat pendukung dalam menciptakan pembelajaran aktif di sekolah kepada Kepala Sekolah SDS HKBP Pembangunan 3 yaitu berupa 1 set Laptop, seminar kit, modul pelatihan pembelajaran secara daring dan paket alat peraga matematika. Seluruh perangkat diberikan guna mendukung peran sekolah di dalam menciptakan suasana pembelajaran baru dengan mengedepankan keaktifan siswa/i di dalam lingkungan sekolah. Harapan dari pemberian bantuan sarana ini yaitu SDS HKBP Pembangunan 3 dapat membantu staf dan guru untuk kegiatan di sekolah terutama kegiatan belajar mengajar. Dan juga siswa dapat menikmati fasilitas yang memang diperlukan oleh mereka dan menambah semangat belajara setiap siswa/i SDS HKBP Pembangunan 3

\section{KESIMPULAN (CONCLUSION)}

Dari semua kegiatan pengabdian kepada masyarakat yang dilakukan dapat disimpulkan bahwa kegiatan ini sangat penting dilakukan karena banyak hal positif yang dihasilkan. Dari kegiatan pertama yaitu Focus Group Discussion diperoleh banyak masukan dan saran dalam memperbaiki keadaan pendidikan di Indonesia. Tetapi banyak hambatan yang membuat setiap saran dapat terlambat dalam pelaksanaanya. Sarana dan prasarana yang kurang memadai dalam melakukan kegiatan belajar dan 
mengajar. Serta keterlibatan alumni dalam membantu membangun dan mengembangkan SDS HKBP Pembanguan 3 Medan.

Untuk kegiatan kedua yaitu pemberian materi pembelajaran aktif serta pemberian sarana pembelajaran sesuai hasil FGD dapat dilihat keinginan untuk mengembangkan sekolah sangat tinggi. Dapat dilihat dari keinginan belajar guru dan staf supaya dapat menerapkan pembelajaran aktif di SDS HKBP Pembanguan 3 Medan. Dan dilanjutkan kegiatan ketiga yaitu pemberian materi untuk menerapkan pembelajaran aktif berbasis teknologi informasi dan komunikasi untuk menyempurnakan pembelajaran aktif berbasis TIK.

Dari ketiga kegiatan tersebut, kesimpulan yang dapat diambil adalah kegiatan pengabdian masyarakat untuk pembelajaran aktif dan TIK sebaiknya diperbanyak dikarenakan masih banyak sekolah yang belum menerapkannya. Sedangkan dari kemajuan zaman yaitu Industri 4.0, pembelajaran berbasis TIK sangat diperlukan. Saran untuk pengabdian berikutnya yaitu pembelajaran berbasis TIK bisa dibuat dengan suatu program supaya lebih memberikan bentuk ilmu pengetahuan.

\section{UCAPAN TERIMAKASIH}

Terimakasih kepada Rektor USU dan LPPM USU yang telah memberikan dana pengabdian tahun 2020 Skema Dosen Wajib Mengabdi.

\section{DAFTAR PUSTAKA}

Afandi, A. (2015). Identifikasi Pengembangan Pariwisata Kota Blitar. Proceeding SENDI_U.

Applegate, D. L., Bixby, R. E., Chvtal, V. dan Cook, W. J. (2006), The Travelling Salesman Problem: A Computational Study, Princeton University Press

Bernhard K. dan Jens V. (2006). Combinatorial Optimization: Theory and Algorithms, Springer.

Brualdi R.A. dan Ryser H.J. (1991). Combinatorial Matrix Theory, Cambridge University Press, Cambridge.

Dorigo M. dan Gambardella L. (1997). Ant colony system: A cooperative learning approach to the travelling salesman problem, IEEE Transactions on Evolutionary Computation Vol.1: 5365.

Dreyfuse, S.E. dan Averill, M.L. (2009a). The Art and Theory of Dynamic Programing, Mathematics in Science Engineering, Volume 130

Fornasini, E. dan Valcher, M.E. (1997) Directed graphs, 2D State Models, and characteristic polynomials of irreducible matrix pairs. Linear Algebra Appl., 263, 275-310.

Primadany, S. R. (2013). Analisis Strategi Pengembangan Pariwisata Daerah (Studi pada Dinas Kebudayaan dan Pariwisata Daerah Kabupaten Nganjuk). Jurnal Administrasi Publik, 1(4), 135-143.

Haque, M.J., dan Magld, K.W. (2012). An intelligent approach for Intrusion Detection based on data mining techniques. Multimedia Computing and Systems (ICMCS), 2012 International Conference on , vol., no., pp.12,16, 10-12 May 2012. 
ISSN Printed Version: 2549-4341

Yan Batara Putra Siringoringo, et al Active Learning Training with Mathematics Tools

Retno, Margono dan Bambang Eka Purnama. ISSN 1979 - 9330. Study of Interaktif Recognition Letter and Number For Children With Computer Multimedia. Indonesian jurnal on Computer Science - Speed (IJCSS) 4 Vol. 3 Nomor 1 Agustus 2008

Script Island. 2008. Panduan Mudah Membuat Animasi. Jakarta: Media Kita.

Tulus, Sawaluddin, T.J. Marpaung, dan M.R. Syahputra. 2018. Making Learning Teaching Materials in School

Based On Information And Communication Technology. Abdimas Talenta. Vol. 3 No. 2 pp. 202-2016

Widyastuti, A. R. (2010). Pengembangan pariwisata yang berorientasi pada pelestarian fungsi lingkungan.

Ekosains, 2(3). 